\title{
A case of endometrial atypical hyperplasia in a nineteen-year-old woman
}

The Department of Obstetrics and Gynecology, Shimane Medical University Kanji Ryuko, Kentaro Takahashi, Ritsuto Fujiwaki, Tomoya Ozaki, Yumi Nishiki, Yumi Watanabe, Manabu Kitao

A nineteen-year-old Japanese woman has complained of general fatigue and excessive menstrual bleeding. Medical workup revealed profound anemia without failure of hemostatic function. Subsequently, she underwent endometrial cytology and endometrial curettage due to assessing uterine bleeding. Endometrial cytology displayed abundant atypical cells with hemorrhagic background. Endometrial biopsy revealed advanced atypical hyperplasia. In this case a reproductive function should be preserved, so that hysterectomy specimen was not available. She has been treated by medroxyprogesterone acetate (MPA) since then. Four weeks later, a follow-up curettage appeared atrophic endometrium without malignant potential. We reported a rare case of endometrial hyperplasia in less than 20 years. Although appropriate treatment for this entity remains a controversial, we should account for endometrial pathology, potentially progressing to malignancy, in very young woman.

Key words : Endometrial atypical hyperplasia-Young woman-MPA

\section{Introduction}

The carcinoma of the endometrium of the uterine corpus has increasingly been the common female pelvic malignancy as opposed to relatively declining incidence of cervical carcinoma. Endometrial carcinoma is primarily in common in the post-

A case of endometrial atypical hyperplasia in a nineteenyear-old woman

Kanji RYUKO, M.D., Kentaro TAKAHASHI, M.D., Ritsuto FUJIWAKI, M.D., Tomoya OZAKI, M.D., Yumi NISHIKI, M. D., Yumi WATANABE, M.D., Manabu KITAO, M.D.

The Department of Obstetrics and Gynecology, Shimane Medical University

論文別刷請求先 昰693 出雲市塩冶町 89 の 1 島根医科大学 産科婦人科 柳光寛仁

平成 6 年 8 月 8 日受付

平成 7 年 6 月 23 日受理 menopausal female, although a quarter of cases occurs in premenopausal, with about $5 \%$ occurring in patients younger than 40 years ${ }^{1}$. Furthermore the patients younger than 30 years were rarely reported, in which polycystic ovary syndrome (PCOS) was often associated with this epithelial malignancy ${ }^{2,3)}$.

Although the advanced endometrial carcinoma appeared to be easily diagnosed with usual diagnostic procedure, the well-differentiated early one may be difficult to distinguish from advanced atypical hyperplasia ${ }^{4}$, particularly in patients without hysterectomy material availability due to the purpose for preserving their reproductive ability.

We experienced a rare case of endometrial atypical hyperplasia in a young woman. This report shows her profile and characteristics. The 
diagnostic difficulty and issue for preserving uterus were described as well.

\section{Case Report}

In the middle of the menstruation, a nineteenyear-old Japanese woman has complained of general fatigue and excessive menstrual bleeding. Her menarche was at the age of thirteen. She had had irregular period, severe hypermenorrhea, and menorrhagia since the menarche. Medical workup revealed profound anemia (hemoglobin $5.5 \mathrm{~g} / \mathrm{d} l$, red blood cell $237 \times 10^{4} / \mathrm{mm}^{3}$ ) without failure of hemostasis. The luteinizing hormone, follicle stimulating hormone and testosterone levels in sera were within normal range. Signs of polycystic ovary syndrome were not identified, supported by transvaginal echography and magnetic resonance image (MRI). Subsequently, she underwent endometrial cytology and systemic currettage of the entire uterine cavity for assessing uterine bleeding and differentiating hormonally regulated bleeding or other benign conditions from malignancy. Endometrial cytology displayed abundant atypical epithelial cells with hemorrhagic background, implying malignancy. On the other hand, the endometrial biopsy revealed atypical hyperplasia, seemingly having been causing hypermenorrhea. Ultrasound examination could not prove multiple cysts in both ovaries, assuming PCOS. Other medical examinations including pelvic computed tomography and MRI denied that this patient was in the advanced stages of endometrial malignancy. Unfortunately, in this case a reproductive function should be preserved at the desire of her family, so that hysterectomy specimen, leading to absolute proof, was not available. Although neither estrogen nor progesterone receptors were found in curettage material, she has been treated by Medroxyprogesterone acetate (MPA) has been administered at a dose of $600 \mathrm{mg}$ daily since then. After four weeks, the second uterine curettage materials showed the atrophic endometrial epithelial cells and the decidual reaction of the stroma, displaying a good response to MPA. At 16 and 24 weeks on medications, subsequent curettage materials were revealed no malignant potential, but atrophic finding was disclosed.

\section{Pathologic Findings}

\section{Endometrial Cytology}

The endometrial cytology revealed papillary and acinar formation of atypical cells with nuclear hyperchromatism. The atypical cells had round or oval nuclei with irregular thick edge, but arrangement of atypical cells preserved polarity, implying well differentiation. The interstitial cells were rarely appeared in slide. The cytological slide was finally interpreted as endometrial atypical hyperplasia (Fig. 1 a, b) .

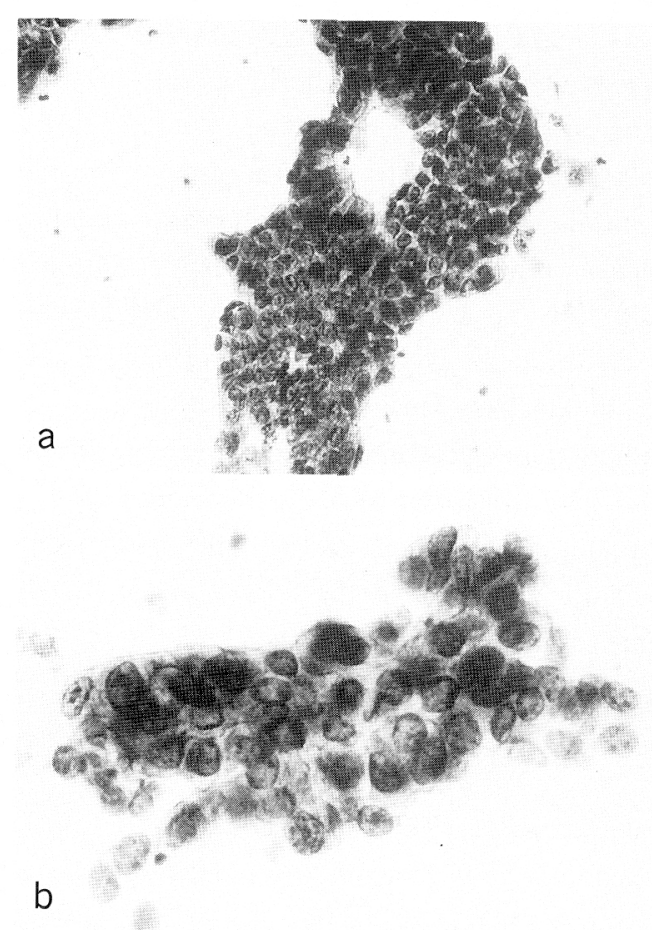

Fig. 1 The endometrial cytology revealed architectural abnormality, such as glandular complexity and crowding, and the cells show nuclear hyperchromatism and nuclear enlargement, and have a increased nuclear-cytoplasmic ratio (Papanicolaou, a $: \times 400, \mathrm{~b}: \times 1000$ ). 


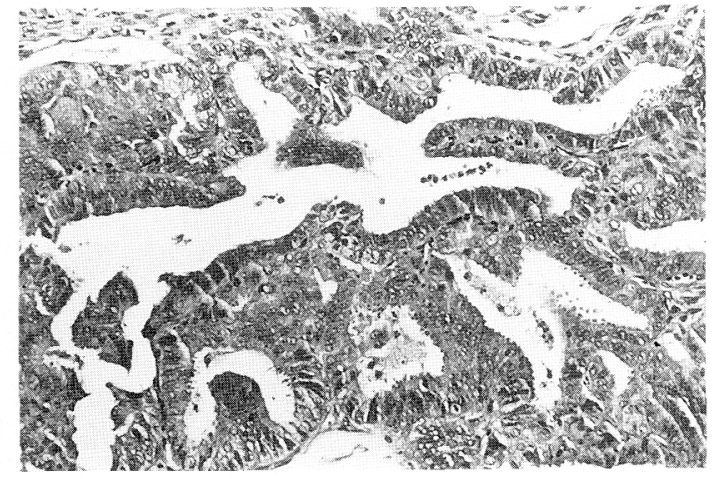

Fig. 2 The endometrial curettage specimen revealed architectural and cytologic atypia, compatible with atypical hyperplasia $(H \& E, \times 400)$.

\section{Endometrial Curettage Specimen}

The enlarged glands with regular outline make the endometrium increase in thickness. The cells lining the glands are enlarged with polarity, display various degree of nuclear hyperchromatism and enlargement, and absolutely have an increased nuclear-cytoplasmic ratio. The prominent features are the back-to-back appearance with scant interstitial area, and the intralumenal papillae. The some areas contain squamous differentiation as morular formation. The curettage material interpreted as endometrial atypical hyperplasia, supporting cytological diagnosis (Fig. 2).

Endometrial Curettage Specimen at Four Weeks after The Initiation of MPA Therapy

A material displayed the atrophic endometrial epithelial cells and the decidual reaction of the stroma (Fig. 3).

\section{Discussion}

Endometrial carcinoma occurs most often in the postmenopausal, although reported in patients as young as age 15 except for the questionable cases in children described in the older literature ${ }^{5)}$. To the best of our knowledge, advanced atypical hyperplasia, however, has been not completely described below the 20 years. We experienced a rare case of atypical endometrial hyperplasia in less than 20

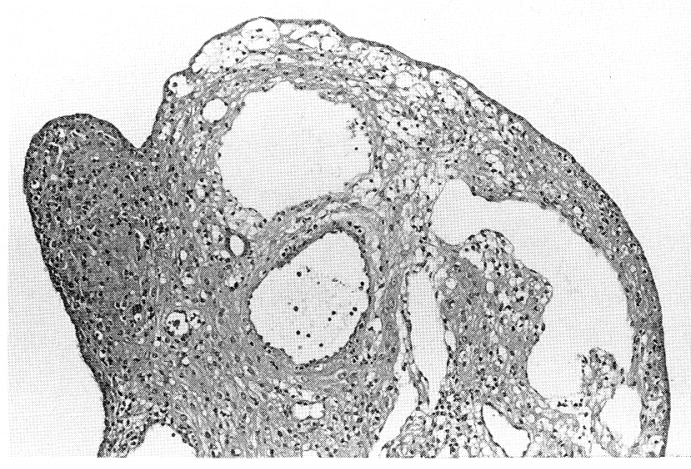

Fig. 3 Endometrial curettage specimen during MPA therapy showed the atrophic epithelial cells and the decidual reaction of the stroma $(\mathrm{H} \&$ $\mathrm{E}, \times 100)$

years, and reported the case.

The well-differentiated endometrial carcinomas are often difficult to distinguish from advanced atypical hyperplasia. The some criteria for differential diagnosis of these two conditions have been offered $^{4,6)}$, but crucial deferences between those conditions have not been clarified. In cases of atypical hyperplasia, the endometrium is increased in thickness by back-to-back glands, most of which have irregular outlines. There are also papillary processes and intralumenal bridges. Moreover, atypical hyperplasia is characterized with cytologic atypia of the glands. The epithelial cells are enlarged, show nuclear hyperchromatism and nuclear enlargement, and have an increased nuclear-cytoplasmic ratio. Nuclei are irregular in size and shape and have a thickened nuclear membrane, prominent nucleoli, and a coarse chromation texture. On one hand, the findings implying adenocarcinoma include an infiltrating cellular or glandular pattern that produces a fibrous desmoplastic reaction in the stroma, confluent glandular bridges, aggregates of glands lacking intravening stroma, and branching, complex papillary epithelial lined processes $^{6)}$. Atypical hyperplasia may focally demonstrate similar changes, but of which the extent of proliferation is commonly in a limited area ${ }^{4)}$. A definitive discrimination, however, seems to be warranted, especially when not availability of 
hysterectomy specimen, so that we really rely upon the judgement of well-experienced gynecologic pathologists.

This case fulfilled almost all criteria written and offered above for pathological diagnosis of atypical endometrial hyperplasia, lacking findings of grade I adenocarcinoma such as infiltrating glandular or cellular pattern, confluent glandular bridges and complex papillary epithelial lined process. Along with these criteria, the patient was diagnosed as endometrial atypical hyperplasia by three skillful pathologists.

Treatment of benign uterine pathologic conditions in women of reproductive age may be conservative. Although appropriate treatment for atypical hyperplasia remains a controversial, we ought to account for endometrial pathology, potentially progressing to malignancy, regardless of very young woman. In early ovarian carcinoma or germ cell tumor, chief concern of attending physician in charge of those who are in childbearing age is usually whether performing hysterectomy with bilateral salpingo-oophorectomy is as optimal treatment for their patients ${ }^{7,8}$. Occasionally we face this setting as well, and always have to give this concern our careful consideration.

Our patient was selected the conservative therapy with endocrine therapy of MPA under pathological diagnosis from only curettage specimen. However in this patient there is other deep concern about the well-being of the reproductive function and furthermore the late effects of chemotherapy on baby born to mother after receiving $\mathrm{MPA}^{7)}$. In this setting some reports described that many patients received MPA or other hormonal medication actually got pregnant, and then bore their babies ${ }^{4,5,8 \sim 10)}$. In those reports, investigators suggested that if regular period is obtained soon after the completion of MPA therapy, her reproductive function would be in a promising state. This important concern was not fully given in the literature to date, so that further experience of the familiar entity is warranted.

Although the sequel of this case was not predict, the recent follow-up work did not display any disappointed finding, and the sufficient quality of life was furnished to the patient and family members.

Authors thank Dr. Shosuke Moriwaki, Saburo Nagaoka and Riruke Maruyama for their special histological analysis of endometrial biopsy.

\section{要 約}

19 歳の子宮内膜異型増殖症を経験した。症例は全身倦怠感と 過多月経を主訴に来院し, エンドサイト法による細胞診と子宮 腔内全面搔爬組織診にて子宮内膜異型増殖症と診断された. 若 年であることを考慮し, 妊孕性保存のため子宮温存し, medroxyprogesterone acetate (MPA) $600 \mathrm{mg} /$ day $に て$ 加療 した. 4 週間後の組織䛦にて萎縮上皮と間質の脱落膜変化を認め るのみで, 異型細胞を認めず, MPA の効果ありと判定した，現 在まで 24 週間 MPA 継続投与し, 再発の兆候を認めず外来管理 中である. 20 歳以下の若年者における子宮体癌および子宮内膜 異型増殖症はまれな病態で, 報告が最近散見されるにすぎない. 特に高齢者と違い妊孕性の温存扔よび薬物療法の適否が問題と なり，その管理に関して慎重さが要求される.

\section{References}

1) Gloeckler-Ries, L.A., Hankey, B.F., Edwards, B.K. Cancer Statistics Review 1973 1987. National Cancer Institute, Division of Cancer Prevention and Control. 1990.

2) Grattarola, R. Misdiagnosis of endometrial adenocarcinoma in young woman with polycystic ovarian disease. Report of a case with an endocrine study. Am. J. Obstet. Gynecol. 1969 ; $105:$ 498 502.

3) Chamlian, D.L., Taylor, H.B. Endometrial hyperplasia in youn woman. Obstet. Gynecol. $1970 ; 36$ : $659 \sim 666$.

4) Lee, K.R., Scully, R.E. Complex endometrial hyperplasia and carcinoma in adolescents and young woman 15 to 20 years of age. Int. J. Gynecol. Pathol. $1989 ; 8: 201 \sim 213$.

5) Kurman, R.J., Kaminski, P.F., Norris, H.J. The behavior of endometrial hyperplasia. Cancer. 1985; $56: 403 \sim 412$.

6) Wu, P-C., Huang, R.-L., Lang, J.-H., Huang, H.-F., Lian, L.-J., Tang, M.-Y. Treatment of malignant ovarian germ cell tumors with preservation of fertil- 
ity : a report of 28 cases. Gynecol. Oncol. $1992 ; 40$ : $2 \sim 6$.

7) Plaxe, S.C., Braly, P.S., Freddo, J.L., Mcclay, E., Kirmani, S., Howell, S.B. Profiles of woman age $30^{-}$ 39 and age less than 30 with epithelial ovarian cancer. Obstet. Gynecol. $1993 ; 81: 651 \sim 654$.

8) Fujii, S. Endometrial hyperplasia in young woman. Obstet. Gynecol. Ther. 1992 ; $64: 131 \sim 136$.
9) Bokhman, J.V., Chepick, O.F., Volkova, A.T., Vishnevsky, A.S. Can primary endometrial carcinoma Stage I be cured without surgery and radiation therapy? Gynecol. Oncol. 1983;20:139 155.

10) Farhi, D.C., Nosanchuk, J., Silverberg, S.G. Endometrial adenocarcinoma in woman under 25 years of age. Obstet. Gynecol. $1986 ; 68: 741 \sim 745$. 